\title{
School Management and Administrative Implications of Video Education Intervention for HIV/AIDS Awareness Among School Children
}

\author{
Edith C. Edikpa ${ }^{1}$, Francisca C. Okeke ${ }^{1}$, Baptista C. Chigbu ${ }^{1}$, Patricia Agu ${ }^{1}$, Amaka E. Onu ${ }^{1}$, Chinwe F. Diara ${ }^{1}$, \\ Bernadette N. Nwafor ${ }^{1} \&$ Paulinus Nwankwor ${ }^{1}$ \\ ${ }^{1}$ Department of Educational Foundations, Faculty of Education, University of Nigeria Nsukka, Nigeria \\ Correspondence: Francisca C. Okeke, Department of Educational Foundations, Faculty of Education, University \\ of Nigeria Nsukka, Nigeria.
}

Received: May 12, 2019 Accepted: June 15, 2019 Online Published: June 17, 2019

doi:10.5539/gjhs.v11n8p17 URL: https://doi.org/10.5539/gjhs.v11n8p17

\begin{abstract}
Objective: The study aimed to examine the effects of a video education intervention for HIV/AIDS awareness among school children and highlight the school management and administrative implications.

Method: A quasi-experimental design was employed. One research question and one hypothesis were postulated for the study. The population of the study was 10,732 students and 3\% sample of the population was used which is 300 students. The null hypothesis formulated at 0.05 level of significance was tested with repeated measures ANOVA.

Results: Results show significant increases from pretest to posttest on the level of HIV/AIDS awareness for participants in the treatment group, relative to control group participants.

Conclusion: The video education intervention significantly increased HIV/AIDS awareness of students in the treatment group compared with those in the control group. The implication for school management and administration were highlighted. Conclusion and recommendations were made among which were that the non-governmental organization should assist in re-educating the youths on this global disease called HIV/AIDS.
\end{abstract}

Keywords: video education, intervention, HIV/AIDS, students

\section{Introduction}

Human immune deficiency virus (HIV) causes AIDS which is acquired immune deficiency syndrome (AIDS). HIV/AIDS is a spectrum of conditions caused by an infection on the body immune system. The virus attacks the immune system and leaves the body vulnerable to a variety of life-threatening illnesses or infections such as cancers, common bacteria, yeast, parasites and viruses that ordinarily do not cause serious disease in people with fully functional immune system but can cause fatal illnesses on people with AIDS (Nwokedi, 2003). World Health Organisation [WHO] (2013) opined that almost 78 million people have been infected with HIV and AIDS virus and about 39 million people have died of HIV. Globally, 35.0 million people living positive (PLP) with HIV and AIDS worldwide. The official report by the Federal Ministry of Health (2010) indicated that 4.1 per cent of people are HIV positive in Nigeria; although, the high rate of infection is still of great concern in some states of the country. HIV/AIDS could be contacted through unprotected sexual intercourse including oral vaginal and anal sex, unscreened blood transfusion, unsterilized objects, sharing of needle, using the same clipper for barbing of hair with an infected person, using unsterilized razor for nails, tattoo or tribal marks from mother to child or pregnant woman who can passively transmit the virus to her fetus. A nursing mother can equally transmit it to her baby through blood contact (Njoku, 2004). HIV has been found in saliva, tears, nevoid system as well in body tissues. However, only in blood transfusion, semen (including pre-seminal fluid or "pre-cum") vaginal secretions and breast milk have been proven to transmit the infection to others (UNICEF, 2007). In other words, HIV is proven to spread through body fluids, breast milk, other body fluids containing blood, cerebrospinal fluids surrounding the brain and the spinal cord, synovial fluid surrounding bone joints and amniotic fluid surrounding a fetus, thereby multiplied after the acquisition.

WHO and UNAID (2010) defined Acquired Immune Deficiency Syndrome (AIDS) as a condition that weakens 
the body's immune system, leaving it venerable to fight off illness. AIDS is the last stage in a progression of diseases resulting from a viral infection known as Human Immune deficiency Virus (HIV or AIDS virus). HIV is a potentially fatal virus affecting all regions of the world. It is a dangerous disease that attacks vital cells of the body causing severe damage to the immune system. AIDS causes immune deficiency and stripes the human body of its defence system, thereby decreasing the level and functions of CD4T lymphocytes (white blood cell). Although it is not everyone who has been infected with HIV that develops AIDS immediately. Very rarely, some individuals can be infected with HIV yet maintain normal immune function and continue to live in good health condition even after twenty years of infection. HIV causes loss of the immune system that results in an immune deficiency disorder, which may eventually result in AIDS (Obionu, 2007).

HIV/AIDS does not have a cure or any vaccine available to prevent infection of HIV/AIDS (USAID 2009). It may not show in the victim's body immediately. AIDS is the fifth leading cause of deaths among people between the ages of 25 and 44 (Federal Minister of Health, 2010). Though, it could be managed and sustained through the taking of drugs like Highly Active Anti-Retroviral Therapy (HAART). People living with HIV may not have any symptoms for 10years or longer. However, it is a long-lasting and deadly illness if not checked and cared for. HIV is not spread by casual contact (such as hugging and touching, that is, touching dishes, doorknobs, or toilet seats previously touched by a person with HIV. Ukachukwu (2005) noted that heterosexual transmission of the HIV virus is the primary mode of spread and the infections appear to be numerous among the youth and young adults who constitute the nation's workforce.

The government of Nigeria has not been able to maintain or sustain a high level of interest in HIV/AIDS rather, they have shifted their interest and campaign to other public health issues affecting the general population forgetting that majority of students in the secondary schools do not know much about the seriousness of this infection and disease called HIV/AIDS (Okolo, 2006). The ages of secondary school students are between 12-19 years. There is a tendency for the risk of being infected irrespective of age. The National Action Committee on AIDS (NACA), State Action Committee on AIDS (SACA) and Local Action Committee on AIDS (LACA) were created in 2000 to coordinate and sustain advocacy by all sectors and at all levels for HIV/AIDS (Adesida, 2012). Education is central and instructive to the individual for the self-sustaining and self-generating process of positive transformation in any community (Ugwu, 2008). Oriajo (2006) noted that education affords human beings the ability and opportunity to explore and exploit their immediate and remote environment from the core of the earth right through to the outer space, for the benefit of the individuals and the society at large. School administrators have an important role to play in ensuring the health of the students by enlightening them on health issues like HIV/AIDS so as to develop health consciousness in them. They should provide medical facilities in the school such as a health Clinic, Sick Bay, First Aid Box, drugs and some medical equipment.

Video education is very pertinent at this point in time. Research has shown that students internalize learning more when they are taught with concrete instructional materials (Nwoji 2013). Awotua-Efebo (2001) established greater achievement evidence of teaching and learning in cognitive and psychomotor skills when visible objects are used. Nwoji (2013) observed that picture presentation that relates to the topics in any lesson or instruction makes the lesson more interesting, vivid and attractive.

HIV/AIDS video education is crucial for an awareness campaign. It is a communication that is not confidential but instructive given that the disease is fast spreading. This instruction is designed to meet desirable public health needs, create awareness, provide needed information and discussion in order to achieve the aim of preventing our youth from indulging in casual sex, use of an unsterilized razor, or unscreened blood for transfusion, so as to prevent more transmission of the virus. Video education may be a reliable awareness intervention for educating secondary school students about HIV/AIDS. Video is the recording and showing of films and events using a video camera, a video recorder, videotapes and a television set (Nwoji, 2013). It can provide excellent result in black and white as well as in colour. It can be played back over and over again for better internalization by the students. Video education is a kind of storytelling intervention with pictures that is necessitated to equip the senior secondary school students with the trends of events that they may experience in tertiary institutions where nobody guides their social, moral and academic life. These young students are the future generation and if not well tutored on their lifestyle, they may fall into disruptive behaviour that ends their lives early. The most devastating aspect of HIV/AIDS is that it is fatal and its infection rate has been very high among the youths who constitute the bulk of the nation's workforce and the future generation parents (Intelligence Community Assessment, 2002).

The HIV highest risk includes men that practice homosexual or bisexual engaging in unprotected sex, intravenous drug users who share needles among themselves, the sexual partners of those who participate in high-risk activities, infants born to mothers with HIV and people who receive a blood transfusion or clothing products (Njoku, 2004). 
HIV does not show in one's face or appearance, it is only when one goes for a test that one will discover one's status whether positive or negative. It takes 2-15 years for HIV infection to manifest or progress to full-blown AIDS (USAID, 2009). Symptoms of HIV/AIDS are dry cough, constant fever, headache, spots and rashes, tuberculosis infections, oral or vaginal thrush, skin infections, sweats particularly at night, consist in-health, weakness and weight loss (UNICEF, 2007) prolonged diarrhea, increasing shortness of breath, pneumonia, enlargement of glands in the neck, sex or genital organs, profound fatigue, white coating on the tongue and white lips or yeast infection of the mouth (Njoku, 2006). Highly Anti-Retroviral Therapy (HAART) has been highly effective in reducing the number of HIV particles in the bloodstream (Edikpa, Okeke, Chinyelugo, \& Nji, 2016).

Effects of HIV/AIDS are numerous, it conditions the victim frame of reference, the way they think, and they isolate themselves from people. It makes the victim lose weight or even sickly which may lead to loss of the victim's job. Friends and family members may stigmatize or discriminate against the infected person. The high cost of Anti- Retroviral therapy/treatment may also be a problem. Thus, the infected person will eventually die. Considering the fact that there is a very high abuse of sex among young people as well as homosexuals and lesbianism (Okolo, 2006), consequently, it then becomes so vital that video education is adapted for use in the creation of awareness on the dangers of HIV/AIDS. The purpose of the study is to investigate the school management and administrative implications on video education intervention for HIV/AIDS awareness among school children.

\section{Research Method}

The quasi-experimental research design was adopted to find out the achievement score of students taught with video education and those taught without video education. The population of the study was all the 10,732 senior secondary students in (SS2, and SS3) in Nsukka Education Zone. The population consists of SS2- 5,533, SS35,199 students, total 10,732 students (source: PRS, PPSMB Enugu 2013/2014). The sample consists of 300 students drawn from two secondary schools in Nsukka education zone. One hundred and fifty students were the sample drawn from each school using simple random sampling technique of balloting without replacement. The total sample drawn was 300 students which constitute $3 \%$ of the total population. According to Okeke (2011) opined that when the study population runs into thousands, a sample of between $2-10 \%$ is ideal. Hence the sample size is 300 students which are $3 \%$ of the population. The researchers developed a questionnaire on HIV/AIDS awareness among school children titled HIV/AIDS Awareness Questionnaire (HAQ). Two senior lecturers from Administration and Planning and Guidance and Counseling unit of Department of Educational Foundations, Faculty of Education, University of Nigeria, Nsukka validated the instrument. The reliability coefficient of the HAAQ was .98alpha. Test-rest of the HAAQ showed $r=.78$. One hundred and fifty students were randomly selected from both schools using balloting written Yes or No to choose those that will receive video education awareness on HIV/AIDS. The same procedure was used for the control group, school A was taught with HIV/AIDS video education intervention awareness that was related to the topic. School B was taught HIV/AIDS with conventional chalkboard and textbook using the same topic and School B served as the control group. The same teacher taught both the intervention and the control group to avoid teacher "effect syndrome", two periods of 40 minutes per lesson was used for both groups twice a week for two weeks. The pretest was given after the first week before the teaching with video education on HIV/AID. The teacher announced the topic and wrote it on the chalkboard. The students were set inducted and the lesson introduced. The control group was taught with textbook and writing on the chalkboard without any video. While the teacher was teaching, the students were allowed to ask questions or contribute. At the end of the lesson, the teacher presented 10 questions for the students to answer. Fifteen minutes were given to write and pass their answer scripts. The CD Rom (Floppy Disk) on HIV/AIDS was used for the awareness intervention group. They had five computers stationed at strategic places. The teacher introduced the lesson, the computer presented step by step tutorial on HIV/AIDS, firstly, showing a film on victims, their skinning figure, spots on their body, the white layers on their mouth, constant dry cough, swollen glands causes of HIV/AIDS, dangers of HIV/AIDS, areas of contact, symptoms, effects and prevention methods. Students were allowed to ask questions where necessary and the lesson continued by the end of the lesson, the students were administered 10 questions covering the topic discussed. 15 minutes were given for them to write and pass their scripts. The questionnaire was administered to both intervention awareness and control group (pretest) and given 15 minutes to answer and submit their answer scripts. This was aimed at checking for prior achievement levels. By the end of the second week, they were given the same questions but the numbers were rearranged, some sentences were changed but still remain the same idea for the posttest. Participants' answer scripts were collected separately and scored. Mean and Standard deviation was used to analyze research question 1 and the percentage of both male and female students. The hypotheses were tested using repeated-measures ANOVA. 


\section{Results}

Table 1. Demographic information of participants

\begin{tabular}{lllll}
\hline \multirow{2}{*}{ Group } & $\mathrm{N}$ & Age & \multicolumn{2}{l}{ Gender } \\
\cline { 3 - 4 } & & $\mathrm{M}(\mathrm{SD})$ & Male, $\mathrm{n}(\%)$ & Female, $\mathrm{n}(\%)$ \\
\hline Treatment & 150 & $15.10(4.02)$ & $60(40)$ & $90(60)$ \\
Control & 150 & $15.26(4.21)$ & $63(42)$ & $87(58)$ \\
\hline
\end{tabular}

Table 1 shows that the mean age of participants in the treatment group was $15.10 \pm 4.02$ years, while that of the control group was $15.26 \pm 4.21$ years. The male participants in the treatment group were $60(40 \%)$ while the female participants were $90(60 \%)$. In the control group, male participants were $63(42 \%)$ whereas females were $87(58 \%)$.

Table 2. Summary Statistics for Repeated-Measures ANOVA on the Impact of Video Education Intervention on HIV/AIDS awareness among Secondary school students

\begin{tabular}{|c|c|c|c|c|c|c|c|c|c|}
\hline \multirow{3}{*}{ Outcome } & \multicolumn{2}{|c|}{$\begin{array}{l}\text { Control group, } \\
n=150\end{array}$} & \multicolumn{2}{|c|}{$\begin{array}{l}\text { Treatment group, } \\
n=150\end{array}$} & \multirow{3}{*}{$D f$} & \multirow{3}{*}{$F$} & \multirow{3}{*}{ Significance } & \multirow{3}{*}{$\eta_{\mathrm{p}}^{2}$} & \multirow{3}{*}{$\begin{array}{l}\text { Observed } \\
\text { power }\end{array}$} \\
\hline & Pretest & Posttest & Pretest & Posttest & & & & & \\
\hline & $M(S D)$ & $M(S D)$ & $M(S D)$ & $M(S D)$ & & & & & \\
\hline HAQ & $15.44(4.80)$ & - & $\begin{array}{l}15.80 \\
(4.95)\end{array}$ & - & $\begin{array}{l}1 \\
299\end{array}$ & .390 & .533 & .002 & \multirow{2}{*}{1.00} \\
\hline HAQ & - & $23.53(4.77)$ & - & $35.63(2.51)$ & $\begin{array}{l}1, \\
299\end{array}$ & 311.37 & .000 & .513 & \\
\hline
\end{tabular}

Note. LHAAQ = Level of HIV/AIDS Awareness Questionnaire.

In Table 2, a repeated-measures ANOVA test conducted indicates that there were no pretest differences on the level of HIV/AIDS awareness between participants in the treatment $(M=15.80, S D=4.95)$ and control $(M=15.44, S D$ $=4.80)$ conditions, $F(1,299)=.390, P=.533, \eta_{\mathrm{p}}^{2}=.002$.

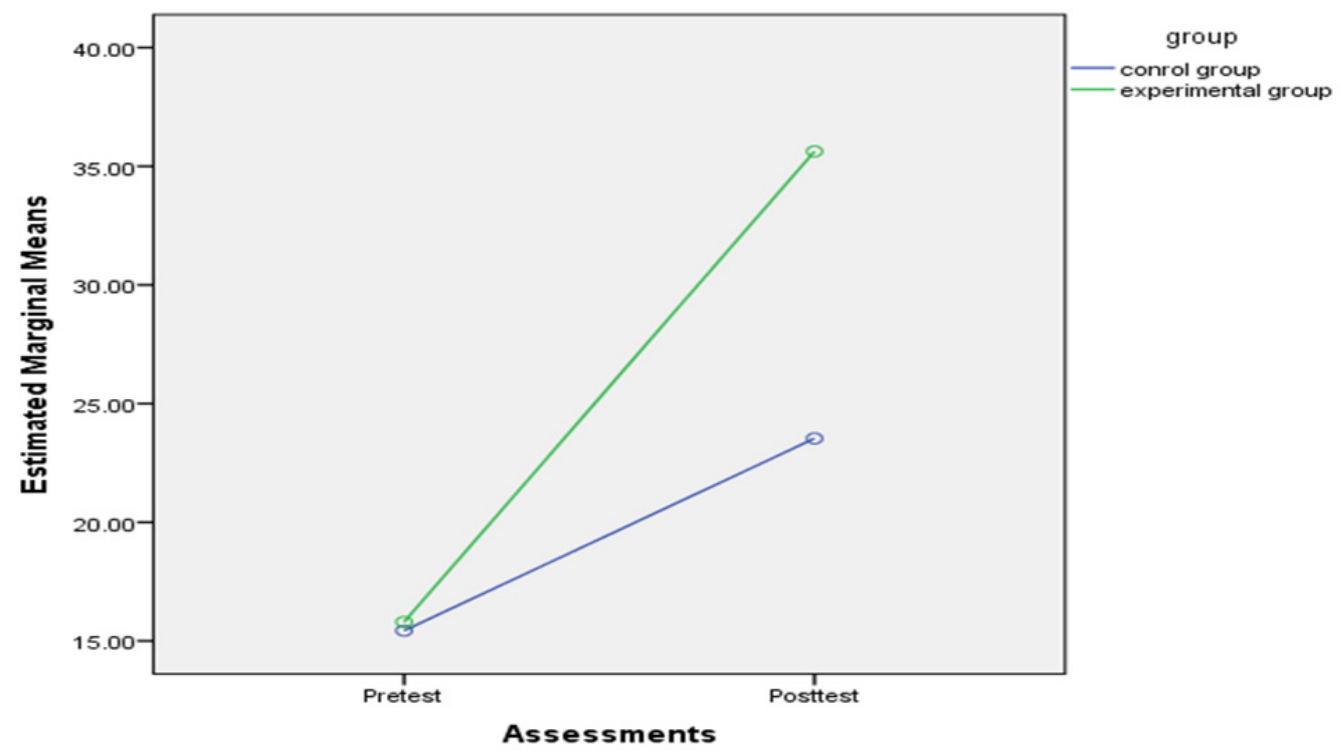

Figure 1. Graph showing the impact of video education intervention on HIV/AIDS awareness 
A repeated-measures ANOVA test also revealed a significant treatment by time interaction effect on the level of HIV/AIDS awareness, $F(1,299)=311.37, P=.000, \eta_{\mathrm{p}}^{2}=.513$. In line with our hypothesis, video education intervention significantly increased HIV/AIDS awareness of students in the treatment group $(M=35.63, S D=2.51)$ compared with those in control group $(M=23.53, S D=4.77)$. Figure 1 graphically demonstrates the mean differences in HIV/AIDS awareness by group.

\section{Discussion}

The video education intervention significantly increased HIV/AIDS awareness of students in the treatment group compared with those in the control group. This finding is in line with the discovery made by Olibie (2005) and Ifeakor (2004) who noted that instructional materials aid the performance of students. It is obvious from the above articulation that learning with video as an instructional material improves learning about HIV/AIDS on part of the students. Okolo (2006) reported that up to 60\% of new HIV infections are found among youths between 15 and 24 years old. The ability of those taught with video education intervention on HIV/AIDS group can be attributed to the step by step presentation of the video in the topic discussed. The school administratoris placed in a better position to make available the necessary materials or equipment that can aid in continuous video education of the students on HIV/AIDS. The school administrator should have the deepest understanding of the impact, symptoms and causes of HIV/AIDS, this is because school administrator has the power to ensure that both the students and staff are safe and in good health. The school head should not stop them from coming to school rather they will help them since they can live a normal life. The school head should organize yearly awareness campaign on HIV/AIDS like workshops, symposiums, seminars for both students and teachers on the dangers of HIV/AIDS to enlighten them. The school administrator as a fact-seeking authority because of his professional competencies, practical experience, expertise and through consist personal experience can find a solution to the problems of the students even before their parents got to know about it. The school administrator should plan, direct, supervise and evaluate student's health situations to check when it becomes worse.

\subsection{Recommendations}

1) The government should support the campaign for HIV/AIDS awareness through conferences, seminars, symposia and workshop.

2) NACA, SACA and LACA should intensify effort in their mandate of carrying bout enlightenment campaign on HIV/AIDS.

3) The non-governmental organizations should assist the government in re-educating the youths on this global disease.

4) People should abstain from sexual intercourse before marriage and encourage others to do the same.

5) Young students should beware of the dangers of "sugar daddies and mummies".

6) People should insist on using screened blood during a transfusion.

7) People should avoid the use of already used strings for injection.

8) There is a need for yearly HIV/AID public awareness campaign for secondary schools students.

\section{Conclusion}

The video education intervention significantly increased HIV/AIDS awareness of students in the treatment group compared with those in the control group. Students exposed to the HIV/AIDS video education intervention benefitted from it positively.

\section{Competing Interests Statement}

The authors declare that there are no competing or potential conflicts of interest.

\section{References}

Awotua-Efebo, E. B. (2001). Effective teaching principles and practice. Paragraphics Port Harcourt.

Federal Ministry of Health. (2010). National health promotion policy, FMOH, Abuja Nigeria.

Ifeakor, A. C. (2004). The use of instructional materials in science pedagogy. The Nigeria Academic Forum, A Multidisciplinary Journal, 6(4), 61-66.

Intelligent Community Assessment. (ICH, 2002). Google search website.

McSweaneyi, I. (2001). Changing behaviour. A challenge to love: science, medicine and love to avoid or cope with AIDS. Benin: Ambassador publication. 
Njoku, O. C. (2006). Combating the spread of HIV/AIDS in Nigeria schools: The role of guidance and counselors. Journal of CUDIMAC, Faculty of Education University of Nigeria Nsukka.

Njoku, Z. C. (2004). Combating HIV/AIDS pandemic: A case study of the contributions of Nsukka catholic Diocese towards changing the sexual behaviours of youths. A Research Report submitted to CODESRIA, Dakar Senegal.

Nwoji, Q. J. (2013). Production and utilization of teaching materials. Timex publishers. Enugu.

Nwokedi, A. (2003).AIDS" Prevention and control. Ibandan Co-operate Graphic Ltd.

Obionu, N. U. (2007). Primary health care for developing countries. Delta Publication (Nigeria) Limited.

Okeke, F. C. (2011). Appraisal of data management practices of the secondary education boards in South East, Nigeria (An Unpublished Ph.D Thesis U.N.N.).

Okolo, A. N. (2006). HIV/AIDS education for sustainable youth empowerment.Implications for the Nigerian society. Journal of Curriculum and Media Technology Research (JOCUMETER) CUDIMAC Nigeria, 2(1) 136-142.

Olibie, E. I. (2005). Influences of mentoring on the teaching competencies of national youth service corps teachers. The Nigeria Primary and Teacher Education Association Journal, 4(8), 58-62.

UNICEF. (2007). Multi-sectional impact of HIV/AID. Retrieved from www.kfforg/hivaids/upload/7661.pdf

USACD. (2009). The world health organization AID Epidemic. Retrieved from http://dataUNAIDS.org (pub) Report/2009/epidemic

WHO and UNAID. (2010). Handbook for improving HIV testing and counselling service, HIV testing and counselling Publication. Geneva, WHO.

World Health Organization. (2013). Global situation and trends. Retrieved from www.who.ent/gco/hiv/en/

\section{Copyrights}

Copyright for this article is retained by the author(s), with first publication rights granted to the journal.

This is an open-access article distributed under the terms and conditions of the Creative Commons Attribution license (http://creativecommons.org/licenses/by/4.0/). 